\title{
Swimming training down-regulates plasma leptin levels, but not adipose tissue ob mRNA expression
}

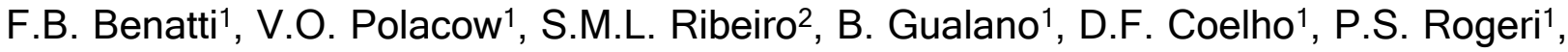 \\ A.S. Costa $^{1}$ and A.H. Lancha Junior ${ }^{1}$

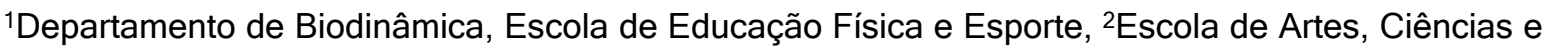 \\ Humanidades, Universidade de São Paulo, São Paulo, SP, Brasil \\ Correspondence to: F.B. Benatti, Av. Professor Mello Moraes, 65, 05508-900 São Paulo, SP, Brasil \\ Fax: +51-11-3091-3136. E-mail: fabenatti@usp.br
}

\begin{abstract}
The aim of the present study was to assess the effects of endurance training on leptin levels and adipose tissue gene expression and their association with insulin, body composition and energy intake. Male Wistar rats were randomly divided into two groups: trained $(\mathrm{N}=18)$ and sedentary controls $(\mathrm{N}=20)$. The trained group underwent swimming training for 9 weeks. Leptin and insulin levels, adiposity and leptin gene expression in epididymal and inguinal adipose tissue were determined after training. There were no differences in energy intake between groups. Trained rats had a decreased final body weight $(-10 \%)$, relative and total body fat $(-36$ and $-55 \%$, respectively) and insulin levels $(-55 \%)$ compared with controls $(P<0.05)$. Although trained animals showed $56 \%$ lower leptin levels ( $2.58 \pm 1.05$ vs $5.89 \pm 2.89 \mathrm{ng} / \mathrm{mL}$ in control; $P<0.05)$, no difference in leptin gene expression in either fat depot was demonstrable between groups. Stepwise multiple regression analysis showed that lower leptin levels in trained rats were due primarily to their lower body fat mass. After adjustment for total body fat, leptin levels were still $20 \%(P<0.05)$ lower in exercised rats. In conclusion, nine weeks of swimming training did not affect leptin gene expression, but did lead to a decrease in leptin levels that was independent of changes in body fat.
\end{abstract}

Key words: Swimming training; Leptin mRNA; Body weight; Adipose tissue; Insulin levels; Rats

Research supported by FAPESP (\#04/03888-3).

Received January 10, 2008. Accepted October 15, 2008

\section{Introduction}

Obesity currently qualifies as a pandemic and its sequelae include diabetes mellitus, hypertension, cardiac diseases, dyslipidemia and some forms of cancer (1). Accordingly, much importance has been given to the understanding of the mechanisms involved in regulating body weight and fat content. The cloning of the mouse $o b$ gene and its receptor led to the discovery of leptin, which soon came to be referred to as "the satiety hormone" (2).

Leptin is expressed and secreted primarily by white adipose tissue and acts through both peripheral and central receptors (3). The latter are located mainly in the hypothalamus (4) in areas related to the control of energy intake and expenditure, thereby suggesting the role of leptin as a central "adiposity signal" in energy homeostasis (5). Leptin levels are strongly and positively correlated with body fat mass $(6,7)$ and leptin expression and secretion seem to be higher in epididymal adipose tissue than in inguinal adipose tissue in rats (8). Nevertheless, many factors regulate leptin synthesis and expression, such as feeding status, sympathetic activity, insulin, exercise and changes in body weight and energy balance (9). Weight loss and fasting are associated with reduced leptin levels while weight gain is associated with an increase in the concentration of this hormone (7).

Although leptin seems to be the prototypic "adiposity signal", insulin can be considered as a second and very important signal that, similar to leptin, acts centrally through hypothalamic neurons and neuropeptides in regions asso- 
ciated with body weight regulation (1). These hypothalamic neurons express leptin receptors as well as insulin receptors, suggesting that leptin and insulin act in concert to promote a decrease in food intake and an increase in energy expenditure and sympathetic nervous system activity (10). The similar catabolic central effects suggest that there might be a co-modulation between leptin and insulin. Levels of both hormones vary in proportion to body fat mass and decrease after weight loss (11). A reduction in leptin levels is observed following a reduction in insulin levels after fasting $(4,12)$.

The effects of exercise training on total energy expenditure, fat mass loss and insulin sensitivity improvement are well known (13). Considering the role of leptin in energy expenditure and its response to changes in body composition, energy expenditure and insulin, exercise training could theoretically be an important modulator of leptin levels. Acute long-term ( $\geq 60 \mathrm{~min}$ ) exercise seems to be associated with a delayed reduction in leptin concentrations $48 \mathrm{~h}$ after exercise $(14,15)$. The effect of exercise training on leptin levels, however, is controversial. Some studies have reported a reduction in leptin levels after chronic exercise training (13,16-19), while others have not observed any changes $(20,21)$. This discrepancy has primarily been attributed to the capacity of exercise to induce fat mass loss $(13,16,17)$. Conversely, a few studies have shown a reduction in leptin levels and/or expression that was independent of any changes in adiposity $(18,19)$. These results suggest that there may be factors beyond adiposity that regulate the reduced leptin levels and expression after endurance training. Insulin appears to be a candidate for such a role, since insulinemia was reduced or insulin sensitivity was enhanced in these studies. However, other lines of evidence supporting this hypothesis are required.

The purpose of the present study was to determine the effect of endurance training on leptin levels, its association with insulin, body fat mass, energy intake and epididymal adipose tissue and inguinal adipose tissue ob mRNA expression.

\section{Material and Methods}

\section{Animals}

Male Wistar rats were housed in individual cages at $25^{\circ} \mathrm{C}$ with a 12-h light/dark cycle. The study was approved by the Ethics and Research Committee of the Physical Education and Sport School (São Paulo University, Brazil). When the animals became adults (body weight from 200 to $300 \mathrm{~g}$ ), they were randomly assigned to one of two experimental groups: exercise-trained $(\mathrm{N}=18)$ and sedentary control $(N=20)$.

\section{Exercise training protocol}

To familiarize the rats with the swimming area, the animals exercised for 5 days for 40 min per day with an increasing load (weights attached to the chest) that finally after 5 days reached $5 \%$ of their body weight (i.e., at the anaerobic threshold for rats during swimming exercise) (22). Animals were then trained for $1 \mathrm{~h} /$ day, 5 days/week for 8 weeks as previously described (23). The $5 \%$ body weight load was kept constant throughout the study. Swimming training was performed in 10 individual round tanks (60 cm in depth $\times 80 \mathrm{~cm}$ in perimeter) filled with circulating water maintained at $30 \pm 2^{\circ} \mathrm{C}$.

\section{Experimental design}

Animals were provided with commercial chow (Nuvilab, Ralston Purina do Brasil, Brazil) and water ad libitum. Food intake was measured three times a week in order to calculate the daily food intake. Body weight was measured once a week. At the end of the protocol, animals were allowed to rest for 66-70 $\mathrm{h}$ after the last training session to eliminate the residual effects of the last exercise bout. Animals were then fasted overnight (12 h) and sacrificed by decapitation.

Two experiments were conducted following the same protocol. In experiment 1, blood samples were obtained after sacrifice for the measurements of leptin and insulin concentrations and the intact carcass was weighed and frozen for body fat mass assessment. In experiment 2, epididymal and inguinal adipose tissues were weighed and frozen immediately for the determination of leptin gene expression.

\section{Oral glucose tolerance test}

The oral glucose tolerance test was performed after exercise training. Glucose was administered orally to the rats ( $2 \mathrm{~g} / \mathrm{kg}$ body weight) following an overnight fast (12 h). Blood glucose levels were measured from the tail vein at 0 , $30,60,90$, and $120 \mathrm{~min}$ after the glucose load. The area under the curve for each group was then calculated as described (24).

\section{Fasting leptin and insulin levels}

Leptin levels were measured by radioimmunoassay (RIA) using a standard commercial kit (Linco Research Inc., USA). The limit of sensitivity was $0.5 \mu \mathrm{g} / \mathrm{L}$ and intraassay CV and inter-assay CV were $9.5 \%$ and $9.2 \%$, respectively. Assays were performed in duplicate. Insulin levels were also measured by RIA using a standard commercial kit (Coat-A-Coat, DPC, USA). The limit of sensitivity was $0.5 \mu \mathrm{g} / \mathrm{L}$ and intra-assay $\mathrm{CV}$ and inter-assay $\mathrm{CV}$ were $8.5 \%$ and $10.3 \%$, respectively. Assays were per- 
formed in duplicate.

\section{Body fat mass assessment}

The carcass (intact body) was immediately frozen for posterior homogenization following sacrifice. Distilled water was added to the carcass, which was then autoclaved for $30 \mathrm{~min}$, followed by homogenization. A sample of the homogenate was added to $3 \mathrm{~mL} 30 \% \mathrm{KOH}(\mathrm{w} / \mathrm{v})$. The lipid was saponified and the non-esterified fatty acids were extracted (25). Relative lipid content was reported as mg/ $\mathrm{g}$ tissue (carcass) and total lipid content as $\mathrm{g}$.

\section{Leptin gene expression}

Leptin gene expression was evaluated by reverse transcription followed by polymerase chain reaction (RT-PCR). The RNA was isolated from the epididymal adipose tissue and inguinal adipose tissue with the Trizol reagent (Gibco Invitrogen, USA). The concentration and integrity of the RNA were assessed by spectrophotometric assays of 260 to $280 \mathrm{~nm}$ (26). cDNA was synthesized using Superscript III reverse transcriptase $\left(200 \mathrm{U} / \mathrm{mL}\right.$, Invitrogen) at $42^{\circ} \mathrm{C}$ for $50 \mathrm{~min}$. The cDNA obtained after reverse transcription was amplified with Taq DNA polymerase (Fermentas, Canada). The primers used for gene amplification were: leptin sense, 5'-GTTCAAGCTGTGCCTATCC-3'; leptin antisense, 5'AAGAATGTCCTGCAGAGAGCCC-3'. For each assay, a hotstart at $94^{\circ} \mathrm{C}$ for $5 \mathrm{~min}$ was performed before the following PCR cycling parameters: denaturation at $94^{\circ} \mathrm{C}$ for $35 \mathrm{~s}$, annealing for $1 \mathrm{~min}$ at the gene-specific annealing temperature and extension at $74^{\circ} \mathrm{C}$ for $60 \mathrm{~s}$. Each sample underwent 32 cycles. PCR products were analyzed by electrophoresis on $1.2 \%$ agarose gels followed by ethidium bromide staining and visualization using Typhoon (Molecular Dynamics, USA). The image was captured with the Scion Image software (Scion Corporation, USA) and imported into NIH image (National Institutes of Health), and the densities of the PCR products were quantified. All values were normalized to levels of the RPL19 gene, which was used as the internal control.

\section{Statistical analysis}

Descriptive data are reported as means \pm standard deviation. Comparisons between groups were made using the Student independent $t$-test for parametric variables and the Mann-Whitney test for non-parametric variables. Pearson correlation coefficients were calculated and multiple and simple regression analyses were performed to test for significance of the linear relationship among variables. Statistical significance was set at $P<0.05$. All analyses were performed using the SPSS software for Windows (version 10.0).

\section{Results}

There was no significant difference in food intake between trained $(0.075 \pm 0.014 \mathrm{~g} / \mathrm{g}$ body weight) and nontrained animals $(0.072 \pm 0.013 \mathrm{~g} / \mathrm{g}$ body weight $)$ in either experiment. It is therefore unlikely that differences in food intake were a factor in this study.

Initial body weight was not significantly different between groups (Table 1). In response to exercise training, trained rats showed a reduction in final body weight $(-10 \%$; $P<0.05)$, relative body fat mass $(-36 \% ; P<0.05)$ and total body fat mass $(-55 \%$; $P<0.05)$ compared with sedentary rats (Table 1). Trained rats also showed a significant reduction in area under the curve and 55 and $56 \%$ lower fasting insulin and leptin levels, respectively (Table 1).

Leptin was highly and positively correlated to body weight, insulin, and relative and total body fat mass (Table 2). We, therefore, conducted a multiple linear regression analysis using the enter method to determine the relative weight of the predictor variables body weight, insulin and relative and total body fat mass on the dependent variable leptin. Regression analysis showed that $88.7 \%\left(R^{2}=0.887\right)$ of the variance in leptin levels could be explained by those predictor variables. When we conducted a multiple linear regression analysis using the stepwise method, total body fat was found to be the best predictor variable to explain leptin level variance $(P<0.01)$.

Caution is required when interpreting these results. Since insulinemia was also significantly correlated with body composition variables (Table 2), multicollinearity was established between insulinemia and body composition variables. Multicollinear predictor variables provide similar information to explain and predict the response of the dependent variable (in this case, leptinemia), making it

Table 1. Effects of exercise training on body weight, relative and total body fat, oral glucose tolerance test calculated area under the curve (AUC), plasma insulin and plasma leptin levels.

\begin{tabular}{lcc}
\hline & $\begin{array}{c}\text { Exercised rats } \\
(\mathrm{N}=8)\end{array}$ & $\begin{array}{c}\text { Sedentary rats } \\
(\mathrm{N}=10)\end{array}$ \\
\hline Initial body weight $(\mathrm{g})$ & $290.18 \pm 59.50$ & $303.65 \pm 65.76$ \\
Final body weight $(\mathrm{g})$ & $384.88 \pm 32.60$ & $425.35 \pm 41.57^{*}$ \\
Total body fat $(\mathrm{g})$ & $18.86 \pm 5.32$ & $34.73 \pm 12.24^{*}$ \\
Relative body fat $(\mathrm{mg} / \mathrm{g})$ & $51.05 \pm 15.2$ & $80.33 \pm 22.3^{*}$ \\
Post-exercise AUC & $8656.7 \pm 510.1$ & $9489.0 \pm 449.0^{*}$ \\
Insulin $(\mu \mathrm{lU} / \mathrm{mL})$ & $5.80 \pm 1.42$ & $12.82 \pm 4.23^{*}$ \\
Leptin $(\mathrm{ng} / \mathrm{mL})$ & $2.58 \pm 1.05$ & $5.89 \pm 2.89^{*}$ \\
Leptin/total body fat & $0.134 \pm 0.023$ & $0.168 \pm 0.038^{*}$ \\
$\quad\left(\mathrm{ng} \cdot \mathrm{mL}^{-1} \cdot \mathrm{g}^{-1}\right)$ & &
\end{tabular}

Data are reported as mean $\pm S D$. * $P<0.05$ compared to exercisetrained group (Student independent $t$-test). 
difficult to decipher the effects that each of the predictor variables exert individually. This can lead to the impairment of the model's predictive ability, which tends to choose only one predictor variable as significant (i.e., the one most strongly correlated with the dependent variable), which, in this case, was total body fat (Table 2). Thus, this result does not mean that the only explanation for leptinemia variance is the variance of total body fat, but instead that this variable is the most adequate fit to the model.

Accordingly, simple linear regression analysis showed that insulinemia variance also explained leptinemia vari-

Table 2. Correlation analysis between plasma leptin, plasma insulin, and body composition.

\begin{tabular}{lcc}
\hline & Leptin $(\mathrm{ng} / \mathrm{mL})$ & Insulin $(\mu \mathrm{lU} / \mathrm{mL})$ \\
\hline Leptin $(\mathrm{ng} / \mathrm{mL})$ & - & $\mathrm{R}=0.820^{*}$ \\
Insulin $(\mu \mathrm{lU} / \mathrm{mL})$ & $\mathrm{R}=0.820^{*}$ & - \\
Total body fat $(\mathrm{g})$ & $\mathrm{R}=0.936^{*}$ & $\mathrm{R}=0.838^{*}$ \\
Relative body fat $(\mathrm{mg} / \mathrm{g})$ & $\mathrm{R}=0.927^{*}$ & $\mathrm{R}=0.804^{*}$ \\
Final body weight $(\mathrm{g})$ & $\mathrm{R}=0.557^{*}$ & $\mathrm{R}=0.636^{*}$
\end{tabular}

${ }^{*} \mathrm{P}<0.05$ (Student independent $t$-test).

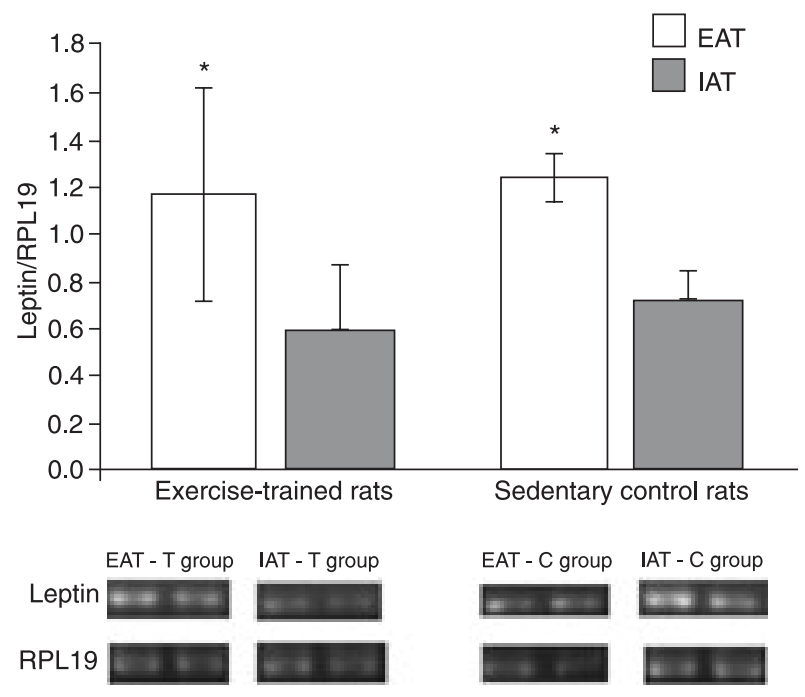

Figure 1. Ratio between leptin gene expression and RPL19 gene (internal control gene) expression in epididymal (EAT) and inguinal adipose tissue (IAT) post-exercise training. Both exercisetrained rats $(T ; N=10)$ and sedentary control rats $(C ; N=10)$ showed higher $o b$ mRNA expression in EAT than in IAT $(\mathrm{P}<$ 0.05). Expression of $o b$ mRNA was not different between groups in either EAT or IAT. *Significant difference between adipose depots $(P<0.05$, Student independent $t$-test). ance $\left(R^{2}=0.67 ; P<0.01\right)$. In addition, when the effect of exercise on leptin independent of total body fat mass was explored, leptin levels were still significantly lower (20\%) in trained animals compared with sedentary controls (Table 1 ), suggesting that other factors in addition to changes in body fat mass do have an effect on leptin levels.

Finally, leptin expression was higher in epididymal adipose tissue than in inguinal adipose tissue in both groups. Leptin expression, however, was not different in either epididymal adipose tissue or inguinal adipose tissue between groups (Figure 1).

\section{Discussion}

The aim of the present study was to investigate the effects of endurance training on leptin levels and its association with other variables such as insulin, body fat mass, energy intake and epididymal adipose tissue and inguinal adipose tissue ob mRNA expression. Our results indicate that nine weeks of swimming training improved insulin sensitivity and reduced total fat mass, body weight, serum insulin and leptin levels, but not leptin gene expression in rats. To our knowledge, this is the first study to demonstrate that a chronic swimming exercise-induced decrease in leptin levels was associated with both adiposity and insulin reduction, but not with ob mRNA expression.

We also found that serum leptin levels were significantly and highly correlated with body fat mass (16-19), body weight $(18,19)$ and insulin levels $(19,27-29)$ (Table 2). A multiple regression analysis using the stepwise method showed that total body fat mass was the best predictor variable to explain leptin level variance, which is also in accordance with previous findings (16-19). After adjusting for total body fat mass, however, leptin levels remained significantly lower in trained rats (Table 1), implying that trained animals were secreting less leptin per gram of adipose tissue than sedentary control animals. These data suggest that factors in addition to changes in fat mass may be responsible for the decreased leptin levels in animals subjected to swimming training.

Similar catabolic central effects suggest that there may be a modulation between leptin and insulin. One hypothesis suggests a cross-talk between the protein tyrosinekinases activated by leptin and those activated by insulin. Common second messengers in the two signaling pathways allow both hormones to trigger the same downstream events through insulin receptor substrate-2 and phosphoinositide 3-kinase (30). A reduction in leptin levels is also observed following a reduction in insulin levels after fasting $(4,12)$. A simple linear regression analysis showed that insulinemia, in addition to adiposity, explained the 
variance in leptin levels. Thus, insulin seems to have an effect on leptin levels independently of changes in adiposity in trained animals. Some studies have attributed changes in leptin levels after endurance training to changes in insulin levels or sensitivity $(18,19,29)$. Perusse et al. (13) attributed the lack of change in leptin levels after adjustment for changes in body fat mass to the lack of improvement in insulin sensitivity after 20 weeks of endurance training. Considine (29) suggested that changes in energy intake or expenditure could be detected by adipocytes, thus influencing leptin synthesis via the actions of insulin. An endurance-training program that improves insulin sensitivity could therefore alter leptin levels independently of fat mass. Studies investigating the underlying mechanisms of this leptin-insulin modulation are necessary for a better understanding of insulin as a modulator of leptin secretion after endurance training.

It is well established that leptin and insulin act in concert on the reduction of food intake and increase in energy expenditure via hypothalamic neurons (28). As a result, the lower leptin and insulin levels found in the trained animals should lead to increased appetite and, consequently, increased food intake. However, trained animals did not increase their energy intake despite the increased daily energy expenditure induced by endurance training. It has been suggested that endurance training could lead to a resetting of leptin levels (19). Lower levels of leptin could therefore be maintained in response to the same amount of body fat mass after endurance training due to a possible improvement of leptin action and sensitivity in the hypothalamus.

Finally, although trained animals showed lower leptin levels, a finding consistent with previous reports $(13,16-$ 19 ), we found no significant difference in adipose tissue (epididymal adipose tissue and inguinal adipose tissue) leptin expression between exercise-trained and sedentary control groups (Figure 1). This finding is in contrast to the study of Zachwieja et al. (31), in which there was significantly lower leptin expression in epididymal adipose tissue, but not in inguinal adipose tissue, after seven weeks of voluntary wheel running. This difference may be due to the time delay after the last exercise session prior to sacrifice (less than $24-\mathrm{h}$ versus approximately $70 \mathrm{~h}$ in the present study). Zheng et al. (32) demonstrated that although leptin expression was decreased in epididymal adipose tissue $2 \mathrm{~h}$ after the last training session following four weeks of treadmill running, $o b$ mRNA levels were back to control levels after a 24-h recovery period from the last training session. The authors suggested that exercise had an acute effect on $o b$ mRNA levels rather than a long-term training effect, and attributed this "reversible change of $o b$ mRNA level" to the short half-life of ob mRNA and the recovery of sympathetic activity and blood insulin levels following exercise.

Ranganathan et al. (33) showed that there was no correlation between adipose tissue ob mRNA and plasma leptin, suggesting that plasma leptin levels may not be solely dependent on adipose tissue leptin expression, but also on posttranscriptional mechanisms such as leptin translation or secretion from the adipocyte. According to Keller et al. (34), changes in free fatty acids, glucose or insulin could, by unknown mechanisms, modify leptin release to the circulation without any alterations in adipose tissue leptin expression. In addition, it has been hypothesized that insulin stimulates leptin secretion without necessarily increasing leptin expression in white adipose tissue $(8,35)$. Therefore, it is possible that the higher insulin or glucose levels found in the sedentary control group worked as a posttranscriptional stimulus that was large enough to promote the conclusion of protein synthesis or the release of synthesized protein. This was not observed in the trained group since these animals presented lower insulin levels.

Nine weeks of swimming training did not affect leptin expression, but did lead to a decrease in plasma leptin levels independent of changes in total body fat mass. These results suggest that there may be factors in addition to fat mass responsible for the decreased leptin levels found in trained animals. Our data also suggested that insulin may be a candidate for such a modulatory role. One could therefore suggest that regulation of leptin in response to endurance training is complex, since exercise training not only promotes changes in body composition, but also in hormone regulation, more specifically in insulin sensitivity, which are both factors that directly influence leptin levels and expression.

\section{References}

1. Niswender KD, Baskin DG, Schwartz MW. Insulin and its evolving partnership with leptin in the hypothalamic control of energy homeostasis. Trends Endocrinol Metab 2004; 15: 362-369.

2. Friedman JM, Halaas JL. Leptin and the regulation of body weight in mammals. Nature 1998; 395: 763-770.

3. Houseknecht KL, Baile CA, Matteri RL, Spurlock ME. The biology of leptin: a review. J Anim Sci 1998; 76: 1405-1420. 
4. Meier U, Gressner AM. Endocrine regulation of energy metabolism: review of pathobiochemical and clinical chemical aspects of leptin, ghrelin, adiponectin, and resistin. Clin Chem 2004; 50: 1511-1525.

5. Funahashi H, Yada T, Suzuki R, Shioda S. Distribution, function, and properties of leptin receptors in the brain. Int Rev Cytol 2003; 224: 1-27.

6. Koerner A, Kratzsch J, Kiess W. Adipocytokines: leptin - the classical, resistin - the controversical, adiponectin - the promising, and more to come. Best Pract Res Clin Endocrinol Metab 2005; 19: 525-546.

7. Rosenbaum M, Nicolson M, Hirsch J, Murphy E, Chu F, Leibel RL. Effects of weight change on plasma leptin concentrations and energy expenditure. J Clin Endocrinol Metab 1997; 82: 3647-3654.

8. Zhang Y, Guo KY, Diaz PA, Heo M, Leibel RL. Determinants of leptin gene expression in fat depots of lean mice. Am J Physiol Regul Integr Comp Physiol 2002; 282: R226-R234.

9. Ahima RS, Flier JS. Leptin. Annu Rev Physiol 2000; 62: 413-437.

10. Benoit SC, Clegg DJ, Seeley RJ, Woods SC. Insulin and leptin as adiposity signals. Recent Prog Horm Res 2004; 59: 267-285.

11. Yildiz BO, Haznedaroglu IC. Rethinking leptin and insulin action: therapeutic opportunities for diabetes. Int J Biochem Cell Biol 2006; 38: 820-830.

12. Bryson JM, Phuyal JL, Proctor DR, Blair SC, Caterson ID, Cooney GJ. Plasma insulin rise precedes rise in ob mRNA expression and plasma leptin in gold thioglucose-obese mice. Am J Physiol 1999; 276: E358-E364.

13. Perusse L, Collier G, Gagnon J, Leon AS, Rao DC, Skinner $\mathrm{JS}$, et al. Acute and chronic effects of exercise on leptin levels in humans. J Appl Physiol 1997; 83: 5-10.

14. Essig DA, Alderson NL, Ferguson MA, Bartoli WP, Durstine JL. Delayed effects of exercise on the plasma leptin concentration. Metabolism 2000; 49: 395-399.

15. Landt M, Lawson GM, Helgeson JM, Davila-Roman VG, Ladenson JH, Jaffe AS, et al. Prolonged exercise decreases serum leptin concentrations. Metabolism 1997; 46: 11091112.

16. Thong FS, Hudson R, Ross R, Janssen I, Graham TE. Plasma leptin in moderately obese men: independent effects of weight loss and aerobic exercise. Am J Physiol Endocrinol Metab 2000; 279: E307-E313.

17. Levin BE, Dunn-Meynell AA. Chronic exercise lowers the defended body weight gain and adiposity in diet-induced obese rats. Am J Physiol Regul Integr Comp Physiol 2004; 286: R771-R778.

18. Hayase H, Nomura S, Abe T, Izawa T. Relation between fat distributions and several plasma adipocytokines after exercise training in premenopausal and postmenopausal women. J Physiol Anthropol Appl Human Sci 2002; 21: 105113.

19. Miyatake N, Takahashi K, Wada J, Nishikawa H, Morishita $A$, Suzuki $\mathrm{H}$, et al. Changes in serum leptin concentrations in overweight Japanese men after exercise. Diabetes Obes Metab 2004; 6: 332-337.

20. Kraemer RR, Kraemer GR, Acevedo EO, Hebert EP,
Temple E, Bates M, et al. Effects of aerobic exercise on serum leptin levels in obese women. Eur J Appl Physiol Occup Physiol 1999; 80: 154-158.

21. Houmard JA, Cox JH, MacLean PS, Barakat HA. Effect of short-term exercise training on leptin and insulin action. Metabolism 2000; 49: 858-861.

22. Gobatto CA, de Mello MA, Sibuya CY, de Azevedo Jr, dos Santos LA, Kokubun E. Maximal lactate steady state in rats submitted to swimming exercise. Comp Biochem Physiol A Mol Integr Physiol 2001; 130: 21-27.

23. Lancha AH Jr, Recco MB, Abdalla DS, Curi R. Effect of aspartate, asparagine, and carnitine supplementation in the diet on metabolism of skeletal muscle during a moderate exercise. Physiol Behav 1995; 57: 367-371.

24. Matthews JN, Altman DG, Campbell MJ, Royston P. Analysis of serial measurements in medical research. BMJ 1990; 300: $230-235$

25. Stansbie D, Brownsey RW, Crettaz M, Denton RM. Acute effects in vivo of anti-insulin serum on rates of fatty acid synthesis and activities of acetyl-coenzyme A carboxylase and pyruvate dehydrogenase in liver and epididymal adipose tissue of fed rats. Biochem J 1976; 160: 413-416.

26. Sambrook J, Gething MJ. Protein structure. Chaperones, paperones. Nature 1989; 342: 224-225.

27. Reseland JE, Anderssen SA, Solvoll K, Hjermann I, Urdal $\mathrm{P}$, Holme I, et al. Effect of long-term changes in diet and exercise on plasma leptin concentrations. Am J Clin Nutr 2001; 73: 240-245.

28. Doucet E, St-Pierre S, Almeras N, Mauriege P, Despres JP, Richard $D$, et al. Fasting insulin levels influence plasma leptin levels independently from the contribution of adiposity: evidence from both a cross-sectional and an intervention study. J Clin Endocrinol Metab 2000; 85: 4231-4237.

29. Considine RV. Invited editorial on "Acute and chronic effects of exercise on leptin levels in humans". J Appl Physiol 1997; 83: 3-4.

30. Nelson D, Cox M. Principles of biochemistry. 4th edn. New York: WH Freeman Company; 2005.

31. Zachwieja JJ, Hendry SL, Smith SR, Harris RB. Voluntary wheel running decreases adipose tissue mass and expression of leptin mRNA in Osborne-Mendel rats. Diabetes 1997; 46: $1159-1166$.

32. Zheng D, Wooter MH, Zhou Q, Dohm GL. The effect of exercise on ob gene expression. Biochem Biophys Res Commun 1996; 225: 747-750.

33. Ranganathan S, Maffei M, Kern PA. Adipose tissue ob mRNA expression in humans: discordance with plasma leptin and relationship with adipose TNFalpha expression. $J$ Lipid Res 1998; 39: 724-730.

34. Keller P, Keller C, Steensberg A, Robinson LE, Pedersen $B K$. Leptin gene expression and systemic levels in healthy men: effect of exercise, carbohydrate, interleukin-6, and epinephrine. J Appl Physiol 2005; 98: 1805-1812.

35. Walker CG, Bryson JM, Bell-Anderson KS, Hancock DP, Denyer GS, Caterson ID. Insulin determines leptin responses during a glucose challenge in fed and fasted rats. Int J Obes 2005; 29: 398-405. 